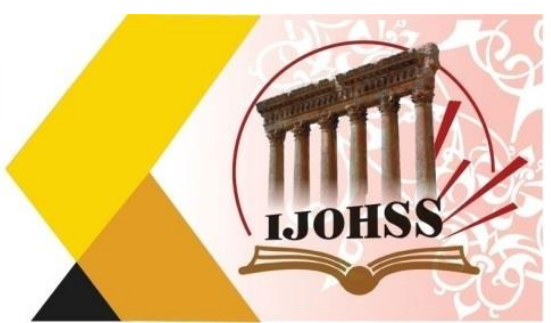

\title{
The Impact of the Physical Education Lesson on the Proficiency of Athletic Movements Drawing for Students of the Fifth Primary Grade In the Center of Babylon Governorate 2018
}

\author{
Dr. Sokina Hassan Khayef Al-Issawi \\ Open Educational College -Al-Qadisiyah Center \\ Iraq
}

\begin{abstract}
The current research aims to identify the impact of the physical education lesson on the proficiency of the drawing of athletic movements by students, the study was carried out in the center of Babylon governorate after the selection of 4 primary schools for boys, the experimental design with the post-test was used, and the partial control of two equal groups (experimental), and a tool was designed to analyze the students' drawings by the content analysis method and giving recurrences for each prominent characteristic in the drawing. The students (the research sample) were randomly distributed among two groups, an experimental and a control group, each group consisting of (10 students) in each school and a total of (40 students). ) They represent the research community as a whole, and the experiment was applied in the first semester of the academic year (2018-2019). The researcher divided the (10 students) from each school into two groups; control and experimental groups, and each group consisted of (5 students). The students of the control experimental group were instructed to draw athletic movements after the experimental group practiced a physical education lesson to show the extent of the impact of the physical education lesson on the drawing proficiency.

The research aims to: - identify the impact of the physical education lesson on the proficiency of athletic movements drawing.
\end{abstract}

Keywords: Physical Education Lesson, Athletic Movements Drawing, Fifth Primary Grade, Babylon Governorate. 


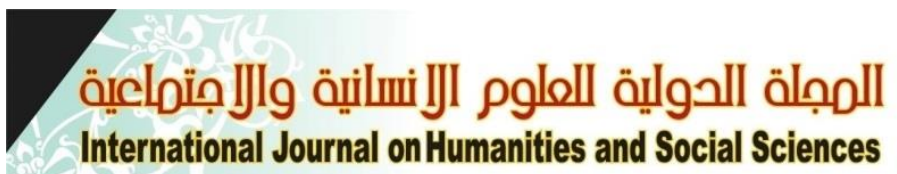

website:www.ijohss.com

Email:editor@ijohss.com

العدد (26)

ISSN: 2415 - 4822

Volume (26) October 2021

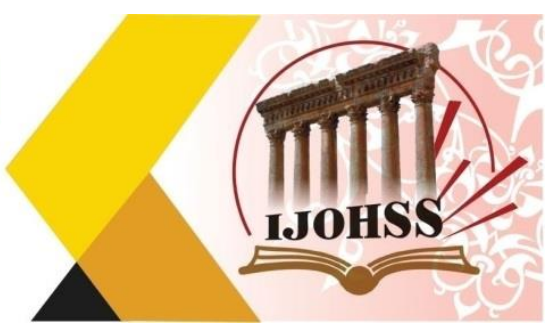

\section{1-Introduction:}

One of the modern objectives that the art education teacher nurtures, beside the traditional goals he recognizes, is what is related to the abilities and skills of the student. That is why it has been useful to examine the relationship between the art education and physical education subjects, to realize the modern significance of this connection.

Art has appeared in education as a means and not a purpose, a way to find that humanitarian content in logic through the integration of personality, and its achievement, which is the achievement of the individual development in its various aspects, to gain psychological health and skill at the same time. The drawing and the artistic expression in general helped the human to blow off what he means unconsciously.

And since the primary stage for a child is one of the important formative phases in a person's life, because it is the phase in which the fundamental basis of the personality are developed, whose features appear in the child's future later .

Therefore, sports and artistic activities are considered as one of the main and basic activities that achieve many objectives, including fitness, activity, creativity and imagination, which have a role in the educational process through the performance of other academic subjects with great enthusiasm and eagerness.

Drawing is a mirror that reflects the child's thoughts. Almost every idea may seek to express itself through drawing. As the child grows, his formative processes grow. The comprehensive development of this wonder language of the hand does not come through the drawing of the schools, but through the human school that works on emerging of this language automatically. Since sports and drawing lessons should be considered as essential lessons in the curriculum of the primary school student, they are even equivalent in importance to other scientific and literary subjects, But this subject is barely realized, so we find some parents looking down on these classes and some students taking them as free classes, while some teachers resort to these classes to follow up their shortcomings in their subjects.. Why this marginalization of these important classes? Why do we still tend to underestimate the importance of children's artistic and athletic talents? And urging them to pay attention to their studies and to leave these subjects that have no future (according to some)? In order to determine these questions and this issue, the researcher touched on trying to find an important relationship and the impact of each subject on the other, between sports and drawing, and to clarify whether there is an impact of the physical education lesson on mastering the drawing of athletic movements? This is what the researcher will try to answer in the course of the current research.

The research aims to: - identify the impact of the physical education lesson on the proficiency of athletic movements drawing. 


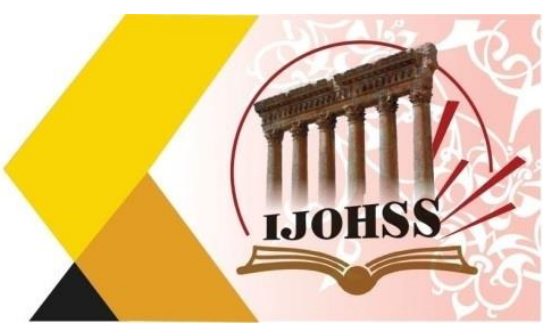

\section{2-research procedures:}

\section{2-1 Research Methodology:}

The researcher used the experimental method for its suitability to the nature of the research as shown in Table (1). The researcher also adopted the descriptive approach in describing the drawings by designing a tool for assessing the drawings.

\begin{tabular}{|c|c|c|}
\hline Group & Independent variable & $\begin{array}{c}\text { Dependent } \\
\text { variable }\end{array}$ \\
\hline Experimental & Introducing physical education lesson & \\
\hline Control & Without exercising & $\begin{array}{c}\text { Proficiency of } \\
\text { athletic } \\
\text { movements } \\
\text { drawing }\end{array}$ \\
\hline
\end{tabular}

\section{2-2-Research community:}

The research community consisted of students in the fifth grade of primary school who are (10-11) years old, and their number is (40 male students), distributed over (4 primary schools) located in the center of Babylon Governorate, for the academic year 2018-2019, and the primary schools were as shown in table (2)

Table (2) shows the schools from which the sample was selected

\begin{tabular}{|c|c|c|}
\hline No. & School name & location \\
\hline 1 & Al-ghad Al-moshreq & $\begin{array}{c}\text { Nader second } \\
\text { district }\end{array}$ \\
\hline 2 & Al-zahawi & $\begin{array}{c}\text { Al-Imam } \\
\text { neighborhood }\end{array}$ \\
\hline 3 & Al-zahraa & $\begin{array}{c}\text { Al-Karad } \\
\text { neighborhood }\end{array}$ \\
\hline 4 & Barada & AL-Bakrly \\
\hline
\end{tabular}

\section{2- 3 research sample:}

A number of (10 students) was taken from each school, which numbered (4 schools), primary (boys), located within the center of Babylon Governorate. In each school the students distributed randomly into two groups each group contains (5 students) with total of (40 students), from each school (10 students) distributed over (4 schools)

\section{2-4- Research tool:}

for the purpose of achieving the objective of the research in identifying the impact of the physical education lesson, it was required to build an objective tool, as in Figure 


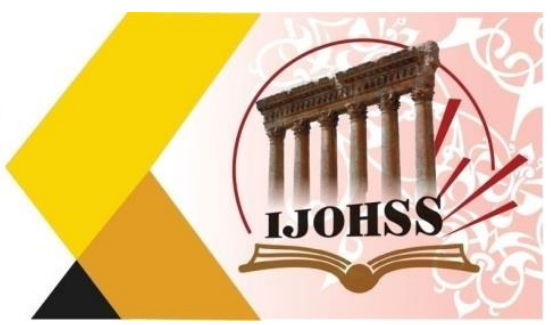

(3), characterized by reliability and validity, to analyze the students' drawings, and in order to achieve this, the following steps were followed:

\section{Tool designing parameters:}

\section{A- Categories of Analysis:}

After the researcher reviewed the students' drawings, a tool was designed by reviewing some of the previous tools used by researchers in previous studies. Some of the items that were included in the analysis were used, and after the tool was designed, it was presented to a group of experts, as shown in the appendix (3) :

Thus, the researcher obtained outcomes for the formation of the tool's structure and its formal construction, and (3) main axes were established in designing the tool. The first axis is related to (the elements of artistic composition), which are (shape, subject and space), while the second axis is the foundations of artistic organization, which is (symmetry, sovereignty, balance and proportion). The third axis was (Description of units) and included the distortion that included (distortion of shape and distortion of color), and thus the tool was limited to three main fields, and sub-characteristics were added to each major field, so the number of main categories reached (8) categories, while the secondary categories reached (11) category.

\section{- Tool validity}

After the main items of the tool and their properties were identified, they were presented to a number of experts and specialists in the field of art education and psychology, to express their views on the extent of the representation of the items and their relevance to the objectives of the research. The experts indicated the need to delete and exclude some items and to add others, so the form included ( 7) main axes and (11) secondary categories (33) sub-characteristics, then they were presented again to a number of experts by meeting them personally, and after the form was collected and filled out in one form, and the percentage of agreement between the experts was extracted using the (Cooper) equation, and The percentage of agreement reached (87\%), which is a percentage of agreement that can be relied upon in calculating the validity of the tool apparently, and it has become in its final form as in Appendix (1) -Units of Analysis

The items of the tool are approved as units of analysis -census units

The researcher used the method of calculating frequencies by giving one point for each apparent characteristic.

Analysis parameters

An analysis form was used for each panel separately

\section{-Tool reliability}

To achieve the objectivity of the analysis that characterizes the content analysis method, the classification categories must be precisely defined, and this objectivity 


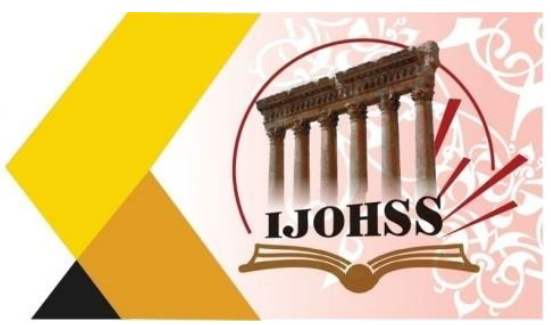

requires reliability, and since the reliability in the content analysis is affected by the experience and the skills of the person conducting the analysis, the type of characteristic, the clarity of the rules of analysis, and the type of analyzed data, through:

1- Agreement between analysts: It means that analysts reach the same results when they individually analyze the same content and the same description.

2- Over time agreement: it means that the researcher reached the same results after analyzing again and after a certain period of time has passed for the same classification and content and by using the same procedures in the analysis.

Therefore, the researcher extracted the reliability of the tool through analysis by selecting (10) of the students' drawings who drew before exercising and (10) of the students' drawing who drew after exercising. The researcher worked with external analysts (*) to analyze the drawings separately. By analyzing the same sample twice in succession and with an interval of (15) days after the analysis, and by applying (Scott) equation, the percentage of agreement between the analysts was (90\%) and between the first analyst and the researcher (85\%), and between the second analyst and the researcher $(87 \%)$ and for the researcher over time $(92 \%)$.

\section{-Applying the experiment and the instrument on the sample:}

Then the researcher applied the experiment to the research sample of (10) students from each school in the center of Babylon Governorate, after the researcher visited the schools, accompanied by the physical education teacher and the art education teacher. as the students was asked to draw some athletic movements before they meet the physical education teacher After (A4) papers were distributed to them and then the students were divided into two groups and one group (the experimental group) was introduced to a physical education lesson to practice the movements and master them in order to ask them later to redraw them, while leaving the students freedom in choosing the movements and the colors they want to use To be later described and analyzed by the (content analysis) method because of the pre-prepared tool and the recurrences has been used as census units "we put a "check mark" on every characteristic that appears in the panel is and the characteristic that does not appear is neglected. After that, the results of the analysis were tabulated into special tables, and then those results were processed statistically. 


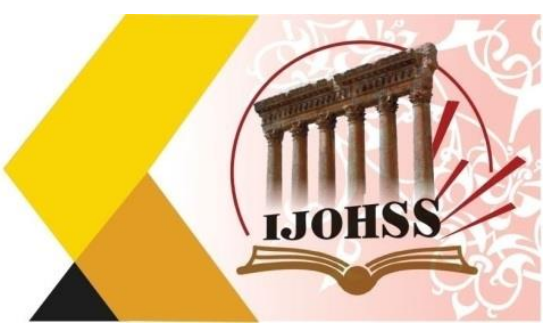

Mathematical and statistical methods used:

1-T-test for two independent samples

$$
\frac{\mathrm{t}^{\mathrm{t}}\left(\mathrm{n}_{1}+\mathrm{n}_{2}-2\right) \mathrm{x}_{1}-\mathrm{x}_{2}}{\frac{\left(\mathrm{n}_{1}-1\right) \mathrm{s}^{2}{ }_{1}+\left(\mathrm{n}_{2}-1\right) \mathrm{s}_{2}^{2}}{\mathrm{~N}_{1}+\mathrm{n}_{3}-2} \mathrm{~N}_{1}+\mathrm{n}_{2}}
$$

2-cooper's equation for tool validity calculation

$$
\text { number of agereement times } \times 100
$$

number of agreement times + number of disagreement times

3-Scott's equation for tool reliability calculation

reliability coeffiecient

$=\frac{\text { total agreement between the observers. the total error in agreement }}{1-\text { the error in agreement }}$

\section{3-Presentation and interpretation of results.}

First, the results presentation:

To reach the objectives of the research and verify the null hypothesis which states that (there is no statistically significant difference at the level $(05,0)$ between the average scores of the experimental group who drew athletic movements after exercising, and the average scores of the control group who drew athletic movements without (the practicing of the physical education lesson) The researcher used the T-Test for two independent samples to test the significance of the difference between the arithmetic mean of the experimental group students' drawings of and the arithmetic mean of the 


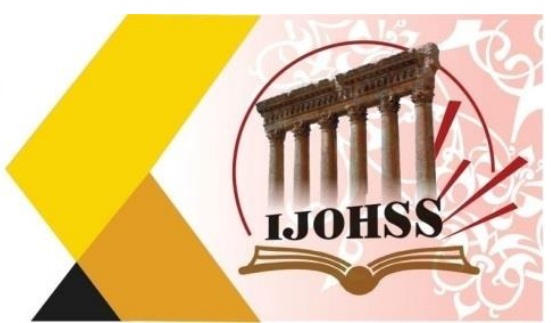

control group students' drawings. The arithmetic mean of the experimental group reached $(26,29)$ and the arithmetic mean of the control group $(61,21)$. The calculated $\mathrm{T}$ value reached $(057.9)$ at the significance level $(0,05)$ and since the calculated $\mathrm{T}$ value is greater than the tabular value, we reject the null hypothesis, and accept the alternative hypothesis, that is, there is a statistically significant difference between the two research groups in favor of the experimental group that drew After practicing the physical education lesson as in Table (3)

Table (3)

\begin{tabular}{|r|r|r|r|r|r|r|}
\hline Group & $\begin{array}{c}\text { Total } \\
\text { number }\end{array}$ & $\begin{array}{c}\text { Arithmetic } \\
\text { mean }\end{array}$ & $\begin{array}{r}\text { Standard } \\
\text { deviation }\end{array}$ & $\begin{array}{r}\text { Calculated } \\
\text { value }\end{array}$ & $\begin{array}{r}\text { Tabular } \\
\text { value }\end{array}$ & $\begin{array}{c}\text { Significance } \\
\text { level }(0,05)\end{array}$ \\
\hline Control & 20 & 21,61 & 2,251 & 9,057 & 1,96 & significant \\
\cline { 1 - 4 } experimental & 20 & 29,26 & 3,306 & & \\
\hline
\end{tabular}

Presentation of the results: After displaying the table on which the recurrences were placed, it became obvious to us the following:

1-Characteristics of students' drawings for the control and experimental group. The drawings analysis tool contained a group of secondary categories divided into a number of apparent contents, which reached (40) features, from which it became obvious in the drawings of the control group (8) features, and in the experimental group (9) features, which are visible As follows:

-2-In the category of figure details, the feature of (lack of detail) was the predominant feature on the drawings of the control group compared to the drawings of the experimental group, which became clear as the feature of (richness in the figure details).

3-In the subject planning category, we find that most of the drawings of the control group were drawn with material lines using the pencil before coloring, while the drawings of the experimental group were drawn with soft lines using the pencil before coloring.

4- In the balance category, the balance of shape and color of the control group was of the same type, while in the drawings of the experimental group it was of a varied type.

5-In the categories of the third axis (Description of Units), which is the distortion, it appeared in the drawings of the control group as a distortion of the shapes in the drawings by the method of magnification and elongation. As for the drawings of the experimental group, most of the shapes in the paintings were drawn in an ordinary way.

\section{Interpretation of the results:}

Through the results that appeared to us, we can explain the superiority of the experimental group that drew after practicing the physical education lesson over the control group that drew without practicing the physical education lesson. The 


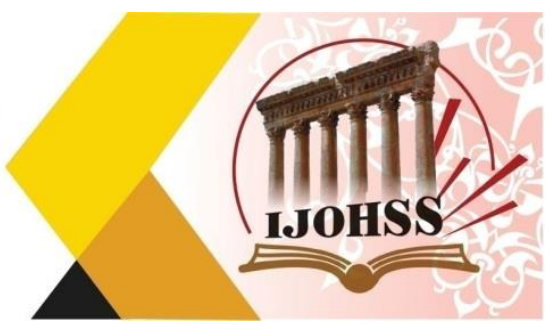

superiority of the experimental group over the control group is attributed to several reasons, including:

1- Practicing sports before drawing creates a kind of motivation towards drawing the largest number of athletic movements and the proficiency of them in the way of drawing.

2- The practice of the athletic movements before drawing worked to stimulate the ideas and imagination of the student, which prompted him to draw the largest possible number of these athletic movements in a more flexible manner

3- -Practicing the physical education lesson before drawing made the drawing lesson more fun, interesting and more endearing to the students.

4- The relationship has become enjoyably reciprocal between sports and drawing, as it made the student more focused on the movement when doing it in the physical education lesson and when drawing it in the art education class.

\section{4-Conclusions and Recommendations:}

\subsection{Conclusions:}

1-practicing sports before drawing leads to raising the level and accuracy of drawing athletic movements.

2-If the student practiced a physical education lesson before starting to draw, it will increase his motivation towards the study subject study, whether it is an art education or a physical education lesson.

3-The physical education lesson has a positive impact on the process of drawing, as it was considered as an educational means to the proficiency of the various kinetic activities in the field of drawing.

4-Adopting the physical study lesson in the stages of study and before the study subjects that require manual skills increases the students' demand and interaction with the study material.

\section{2- Recommendations:}

1-Putting the physical education lesson in the school schedule before the study subjects that require manual skill in the field of drawing, such as science or geography, and in the advanced stages, such as physics, chemistry, biology and other subjects because of its impact on developing and activating technical skills that need drawing skill.

2-Conducting teaching sessions for male and female teachers on how to use teaching methods related to fun and entertainment, such as practicing students' use of some athletic movements before starting to write or draw to stimulate blood circulation and stimulate the student's brain. 


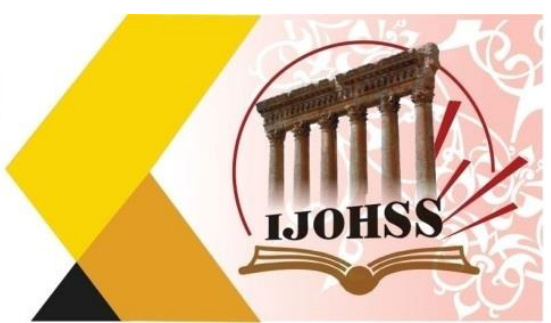

\section{References}

1. Salih, Qasim Hussein: The Psychology of Perceiving Color and Shape, Dar AlRasheed Publishing, Baghdad, 1982.

2. -Attia, Mohsen Mohamed: Concepts in Art and Beauty, World of Books, Cairo, 2005.

3. Ibn Manzoor, Jama al-Din Muhammad bin Makram al-Ansari: Lisan al-Arab, part 5, chapter of the Alif, Arab House of Composition and Translation, pg. 60.

4. Saliba, Jamil: The Philosophical Dictionary, Part 1 and Part 2, Edition 1, Lebanese Book House, Beirut, 1982.

5. Al-Thanawy, Muhammad Ali bin Ali bin Muhammad: Discovering the Conventions of Arts, Volume 1, i 1, Dar al-Kutub al-Ilmiyya, Beirut, Lebanon, 1998.

6. Al-Khouli, Amin Anwar: Sports and Society, Knowledge, No. 216, National Culture, Arts and Letters, Kuwait, 1996.

7. Maser, Muhammad Khair: School sports activity and its educational and social role, a study paper presented to the scientific symposium entitled School Physical Education between Science and Application, United Arab Emirates University, 1990.

8. Ayesh, Amal Rashid and Wedad Yousef Muhammad: The effect of a physical education lesson on the academic achievement of fourth-grade students, research submitted to Al-Fath Journal, No. 51, to the Diyala Education Directorate, 2012.

9. Al-Azmawi, Ibrahim: The Psychology of Childhood, Fatwa and Youth, Dar AlFikr Al-Jamii, Beirut, 1985.

10. Thomas, Emile: The environment and its impact on the life of the population, see: Zakaria Ahmed El-Baradei, Dar Al-Geel for printing, Cairo, 1977.

11. Al-Bassiouni, Mahmoud: Issues of Art Education, printed and published: Dar AlMaaref, Egypt, 1969.

12. Al-Kinani, Majid Nafie Abboud: Evaluating the Art Education Curriculum in Secondary Schools, Master's Thesis (G.M), Baghdad, 1989.

13. Al-Jubouri, Mahmoud Shukr Mahmoud: Art Education and its educational implications, The Small Encyclopedia, House of General Cultural Affairs, Baghdad, 1989.

14. Al-Sunni, Ahmed Qassem and Al-Mahroos, Abbas Saeed: A Teacher's Guide to Art Education in the Preparatory Stage, 1st Edition, Ministry of Education, Bahrain.

15. Al-Nuaimi, Eid Al-Moneim Mir: Evaluating the Teaching of Applied Students in the College of Fine Arts, Al-Ummah Press, University of Baghdad, Baghdad, 1990.

16. Al-Bassiouni Mahmoud: Artistic Culture and Education, Dar Al-Maaref, Egypt, 1965.

17. Qashlan, Mamdouh: Special Methods in Art Education, Artistic Arab Press, Damascus, 1963

18. Shenouda, Naji: Towards a better understanding and development of children's drawings, Khotwa Magazine, No. 16, published by the Arab Council for Childhood and Development, 2002. 


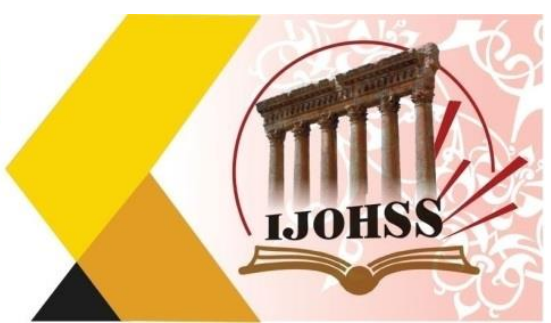

19. Judy, Muhammad Hussein: Towards a new vision in art and art education, Saad Press, Baghdad, 1988.

20. Othman, Abla Hanafi: What do children's arts mean to us and the child, Khatwa Magazine, Issue 16, issued by the Arab Council for Childhood and Development, 2002.

21. Sahara Net Oasis http: www.sahara. .

22. Abdel Mawla, Taghlib Abdel Mawla Jalil, Children's and Innate Drawings, Master's Thesis (G.M), College of Fine Arts, University of Babylon, 2008.

23. Shaabeth, Suhad Abdel Moneim Abdel Mohsen: Characteristics of children's drawings and their relationship to intelligence, Master's Thesis (G.M) Babylon University, College of Fine Arts, 2002.

- www.9009le) (www.alhkeka.com)

Appendix (1) Experts names

\begin{tabular}{|r|l|l|l|l|}
\hline \multicolumn{1}{|c|}{ No. } & \multicolumn{1}{|c|}{ Expert's name } & Scientific title & Specialization & workplace \\
\hline 1 & Abdul Hadi Hassan & Dr. Professor & $\begin{array}{l}\text { educational } \\
\text { psychology }\end{array}$ & $\begin{array}{l}\text { Open } \\
\text { Educational } \\
\text { College }\end{array}$ \\
\hline 2 & Firas Mahmoud Mohamed & Dr .Professor & $\begin{array}{l}\text { art education } \\
\text { philosophy }\end{array}$ & $\begin{array}{l}\text { Babylon } \\
\text { Education } \\
\text { Directorate }\end{array}$ \\
\hline 3 & Raed Mohsen Obaid & Dr .Professor & $\begin{array}{l}\text { Teaching } \\
\text { Methods/Physical } \\
\text { Education }\end{array}$ & $\begin{array}{l}\text { Open } \\
\text { Educational } \\
\text { College }\end{array}$ \\
\hline 4 & Sadiq Kazem Hussein & Dr .Professor & $\begin{array}{l}\text { art education } \\
\text { philosophy }\end{array}$ & $\begin{array}{l}\text { Open } \\
\text { Educational } \\
\text { College }\end{array}$ \\
\hline
\end{tabular}




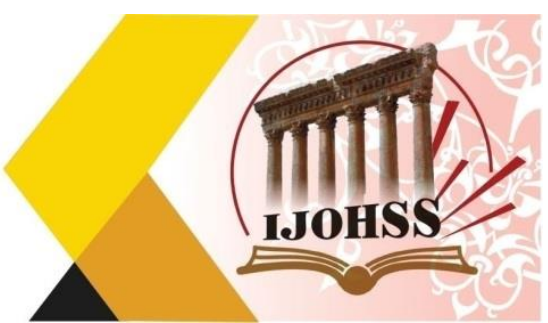

\section{Appendix (2) Student drawing analysis tool in its final form}

\begin{tabular}{|c|c|c|c|}
\hline The first axis & Main Categories & secondary categories & $\begin{array}{l}\text { apparent content } \\
\text { standard }\end{array}$ \\
\hline \multirow{12}{*}{$\begin{array}{l}\text { Technical composition } \\
\text { elements }\end{array}$} & \multirow[t]{6}{*}{ the shape } & \multirow[t]{3}{*}{ formal movements } & Multiple moves \\
\hline & & & normal movements \\
\hline & & & specific movements \\
\hline & & \multirow[t]{3}{*}{ Organize shapes theme } & top of the panel \\
\hline & & & down the panel \\
\hline & & & middle of the panel \\
\hline & \multirow[t]{3}{*}{ subject } & \multirow[t]{3}{*}{ planning } & $\begin{array}{l}\text { Soft lines with a pencil } \\
\text { before coloring }\end{array}$ \\
\hline & & & $\begin{array}{l}\text { Sharp lines with a } \\
\text { pencil before coloring }\end{array}$ \\
\hline & & & soft sharp lines \\
\hline & \multirow[t]{3}{*}{ space } & \multirow[t]{3}{*}{ Space area } & Wide \\
\hline & & & Limited \\
\hline & & & closed \\
\hline Second axis & Main categories & secondary categories & $\begin{array}{l}\text { apparent content } \\
\text { standard }\end{array}$ \\
\hline \multirow{3}{*}{$\begin{array}{c}\text { Foundations of } \\
\text { technical organization }\end{array}$} & \multirow[t]{3}{*}{ Dominion } & \multirow[t]{3}{*}{ type of dominion } & diverse \\
\hline & & & dominion of color \\
\hline & & & dominion of form \\
\hline second axis & Main categories & secondary categories & $\begin{array}{l}\text { apparent content } \\
\text { standard }\end{array}$ \\
\hline \multirow{12}{*}{$\begin{array}{l}\text { Foundations of } \\
\text { technical organization }\end{array}$} & \multirow[t]{6}{*}{ Balance } & \multirow[t]{3}{*}{ shape balance } & diverse \\
\hline & & & symmetric \\
\hline & & & asymmetric \\
\hline & & \multirow[t]{3}{*}{ color balance } & diverse \\
\hline & & & symmetric \\
\hline & & & asymmetric \\
\hline & \multirow[t]{6}{*}{ Suitability } & \multirow[t]{3}{*}{ shape suitability } & proportional to space \\
\hline & & & $\begin{array}{l}\text { disproportionate to } \\
\text { space }\end{array}$ \\
\hline & & & Various fit \\
\hline & & \multirow[t]{3}{*}{ color suitability } & diverse \\
\hline & & & Total \\
\hline & & & partial \\
\hline Third axis & Main categories & secondary categories & $\begin{array}{l}\text { apparent content } \\
\text { standard }\end{array}$ \\
\hline \multirow[t]{6}{*}{ Units description } & \multirow[t]{6}{*}{ Distortion } & \multirow[t]{3}{*}{ shape distortion } & There is no distortion \\
\hline & & & Zoom in \\
\hline & & & zoom out \\
\hline & & \multirow[t]{3}{*}{ color distortion } & chromatic saturation \\
\hline & & & chromatic poverty \\
\hline & & & unnatural \\
\hline
\end{tabular}

